\title{
MAIN HYDROLOGICAL FEATURES AND RECHARGE ANALYSIS OF THE CAPOSELE SPRING CATCHMENT, SOUTHERN ITALY
}

\author{
GLAVNE HIDROLOŠKE ZNAČILNOSTI IN ANALIZA NAPAJANJA \\ ZALEDJA IZVIRA CAPOSELE, JUŽNA ITALIJA
}

\author{
Francesco FIORILLO ${ }^{1}$, Libera ESPOSITO ${ }^{1}$, Mauro PAGNOZZI ${ }^{1}$, \\ Zoran STEVANOVIĆ ${ }^{2} \&$ Gerardo VENTAFRIDDA $^{3}$
}

\begin{abstract}
UDC 556.33(450.7)

Francesco Fiorillo, Libera Esposito, Mauro Pagnozzi, Zoran Stevanović \& Gerardo Ventafridda: Main hydrological features and recharge analysis of the Caposele Spring catchment, southern Italy

The Caposele spring supplies with water the Puglia region (southern Italy) since the beginning of the twentieth century by a wide and long (about $400 \mathrm{~km}$ ) gravity-aqueduct system. Systematic spring discharge measurements exist since 1920. The annual mean discharge of spring is about $4 \mathrm{~m}^{3} / \mathrm{sec}$, the spring catchment of the of Mt. Cervialto karst massif is estimated on more than $100 \mathrm{~km}^{2}$. The spring regime is characterised by absence of abrupt peaks in the hydrographs; the flood period occurs in spring-summer time, and the minimum during the autumn-winter time. Thus, the regime is almost opposite that of rainfall which allows a convenient management of the source. The historical data have shown that spring discharge depends also on the hydrological conditions of the previous year because the "memory effect" of aquifer. The recharge processes have been evaluated using a daily scale recharge model, calibrated on long term annual scale. The results allow to estimate the inertial behaviour of the aquifer, by the difference of recharged and discharged water volume during a hydrological year: after a wet year, an amount of water volume is retained into the aquifer and constitutes the surplus volume stored; after a dry year, the aquifer discharges a water volume higher than the recharged volume (a deficit in storage).
\end{abstract}

Key words: karst aquifer, recharge model, spring discharge, storage, southern Italy.

\begin{abstract}
Izvleček
UDK 556.33(450.7)

Francesco Fiorillo, Libera Esposito, Mauro Pagnozzi, Zoran Stevanović \& Gerardo Ventafridda: Glavne hidrološke značilnosti in analiza napajanja zaledja izvira Caposele, južna Italija

Izvir Caposele je od začetka 20. stoletja glavni vodni vir Apulije (južna Italija). Voda je od izvira do mest gravitacijsko speljana po približno $400 \mathrm{~km}$ dolgem akvaduktu. Sistematične meritve pretoka potekajo od leta 1920, povprečni pretok izvira je $4 \mathrm{~m}^{3} / \mathrm{s}$, območje napajanja je kraški masiv gore Cervialto s površino preko $100 \mathrm{~km}^{2}$. Značilnosti izvira so odsotnost izrazitih vrhov v pretočnem hidrogramu, visok pretok v pomladansko-poletnem času in nizek pretok v jesensko-zimskem obdobju. Režim pretoka izvira je skoraj obraten od padavin, kar omogoča preprosto upravljanje vodnega vira. Zgodovinski podatki kažejo, da je pretok odvisen od hidroloških razmer v predhodnem letu, kar je posledica velikega »spominskega učinka« vodonosnika. Napajanje sistema smo ocenili na podlagi dnevnega modela napajanja, umerjenega na dolgoročno letno obdobje. $\mathrm{Z}$ razliko med napajanjem in odtokom $\mathrm{v}$ hidrološkem letu, smo ocenili inercijsko obnašanja vodonosnika. Izkaže se, da se v letu z veliko padavinami presežek napajanja skladišči v vodonosniku, v suhem letu pa je volumen odtoka večji od volumna odtoka. Ključne besede: kraški vodonosnik, model napajanja, pretok izvira, skladiščenje, južna Italija.
\end{abstract}

\footnotetext{
${ }^{1}$ Department of Science and Technology, University of Sannio, via dei Mulini 59/A, 82100 Benevento, Italy, e-mail: francesco. fiorillo@unisannio.it, libera.esposito@unisannio.it,pagnozzi.mauro@libero.it

${ }^{2}$ Centre for Karst Hydrogeology, Department of Hydrogeology, University of Belgrade - Faculty of Mining and Geology, Djušina 7, 11000 Belgrade, Serbia, e-mail: zstev_2000@yahoo.co.uk

${ }_{3}$ Acquedotto Pugliese S.p.A., Bari, Italy, e-mail: g.ventafridda@aqp.it
}

Received/Prejeto: 19.03.2018 


\section{INTRODUCTION}

The Caposele Spring is located on the north side of $\mathrm{Pi}$ centini Mountains, inside the village Caposele, Campania Region, and constitutes the beginning of the Sele River which flows into the Tyrrhenian Sea (Fig. 1).

This spring constitutes one of the most strategic water resources in Italy, as it supplies with water the Puglia Region since the beginning of the twentieth century by a wide and long gravity-aqueduct system. The first part is a $15.3 \mathrm{~km}$ long tunnel, namely "Pavoncelli Tunnel" from the name of its designer, crossing the water divide between Sele and Ofanto rivers (which corresponds also to water divide between Tyrrhenian and Adriatic seas); only by gravitational movement, water reaches localities up to $400 \mathrm{~km}$ far from the spring. Spring water reached for the first time the town of Bari in 1915 and the Salento area few years later. After the II. World War further water recourses have been used to satisfy the increasing water demand of Puglia Region; in particular, other springs of Picentini Mountains (Cassano Springs) are added to the aqueduct channel. The hydraulic works of the Pugliese
Aqueduct constitute the most wide and complex aqueduct system of Italy, and probably of Europe.

Systematic discharge measurements of Caposele Spring exist since 1920, and allow investigation of the long-term behaviour of this spring. Besides, as no manmade modifications or groundwater pumping occurred in the spring catchment, the Caposele Spring has a strictly control by the climate. In particular, because the aquifer act as large natural reservoirs of water, spring discharges reflect periods of poor or abundant rainfall, as well as long term climate change (Fiorillo 2009).

Insufficient recharge due to poor annual rainfall results in flat spring hydrographs (without flood) that indicate a continuously decreasing discharge for the entire hydrological year. Flat spring hydrographs reveal a drought, which is characterised by a prolonged shortage of water that induces a reduction in discharge during the following year as well in this spring. The historical data have shown that each hydrological year depends also on the previous year because the "memory effect" of aquifer, and highlights the inertial behaviour of the aquifer. Due

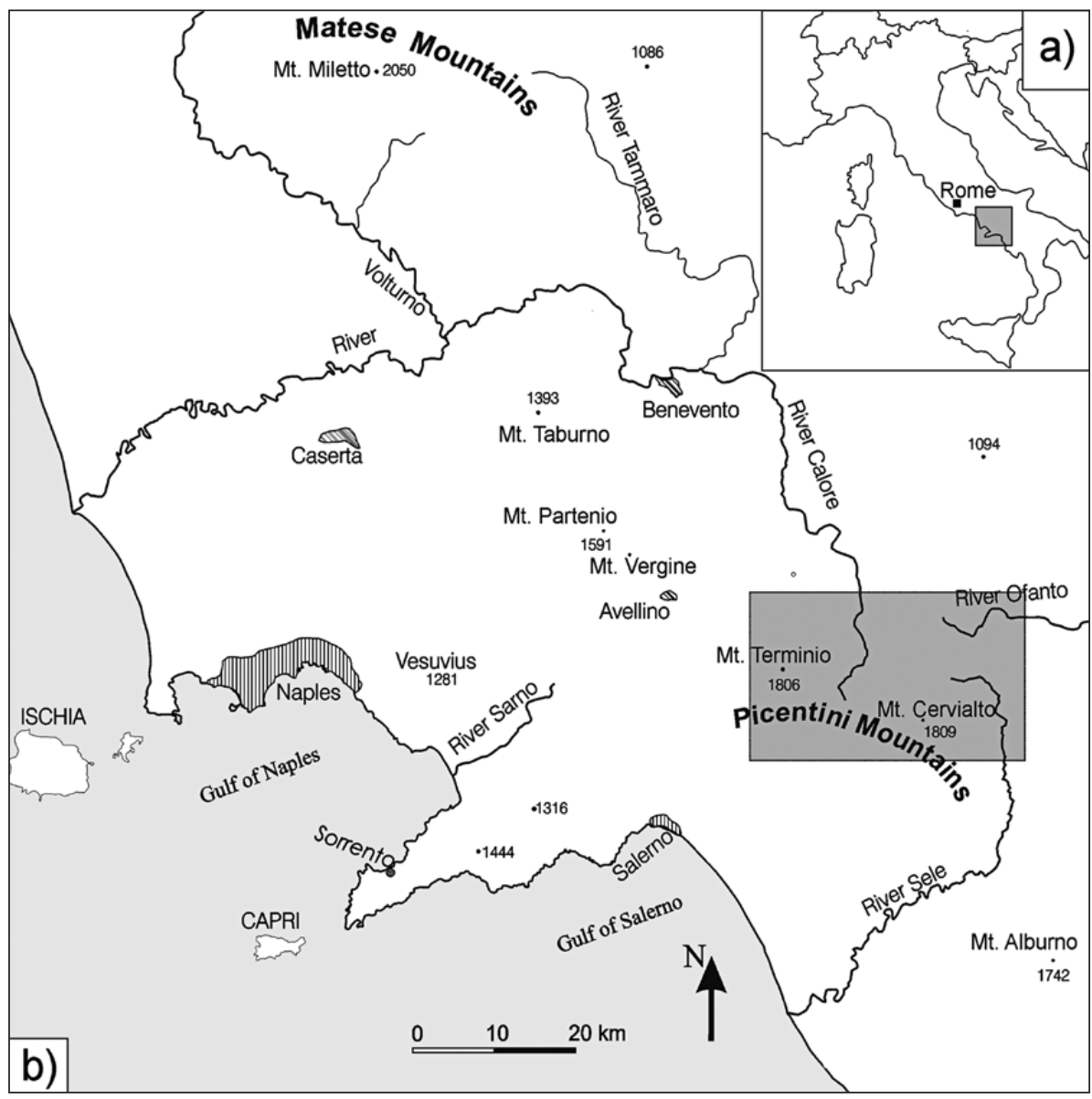

Fig. 1: a) Italy, b) Map of the western Campania Region with Caposele Spring location; rectangular area is detailed in Fig. 2. 
to a long historical series and the specific karst spring regime, a flat hydrograph can be forecast during the winter, thereby providing a useful tool for water management (Fiorillo 2009).

It has been found that spring discharge is controlled by rainfall cumulated over a long period of time; droughts are induced by scarce rainfall over a long period of time (Fiorillo \& Guadagno 2010). The relation between spring discharge and rainfall has been analysed also to investigate on the time required for water to flow through the karst aquifer. In particular, Fiorillo and Doglioni (2010) investigated this relation by crosscorrelation analyses; the input signal involved multiple rainfall time series (cumulative rainfall over varying time windows), while the time series of daily spring discharges were used as the output signal. It has been found out that 270 days cumulative rainfall with a lag of $k=41$ days was best correlated to the Caposele Spring discharge (Fiorillo \& Doglioni 2010), but also longer and shorter time interval of rainfall contributes to discharge as indicated by the results obtained with cumulative rainfall time series. The wide range of time needed for water to reach the spring has to be related to the morphological and hydrogeological setting of the basin, in terms of distance of each point from the spring, thickness of the vadose zone, and the karst condition of the epikarst, the vadose zone and the saturated zone (Fiorillo \& Doglioni 2010).

In this study the recharge processes have been evaluated, using the recharge model of karst massifs provided by Fiorillo et al. (2015). After the estimation of the recharge coefficient (ratio between the output spring and input rainfall), the annual recharge has been used to calibrate a daily scale model, which allows to estimate the amount of effective rainfall, which is retained as soil moisture, the amount reaching the water table (recharge sensu stricto), and the amount of rainfall, which develops the runoff and leaves the catchment.

The recharge processes have been evaluated for the recent hydrological years, and the inertial behaviour of the aquifer has been defined analytically by the difference of recharged water volume and discharged water volume during a hydrological year.

\section{MATERIALS AND METHODS}

\section{GEOLOGICAL AND HYDROGEOLOGICAL FEATURES}

The northern sector of Picentini Mountains (Figs. 1 \& 2 ) is characterized by two main massifs, the Cervialto and Terminio mountains, which provide spring water to many aqueducts of southern Italy. In general, these massifs are characterized by high slope angles, connected to Quaternary tectonic uplift, which has caused several fault-scarp in the carbonaceous rocks, actually showing a slope angle around $35^{\circ}-45^{\circ}$.

The ground-elevation reaches 1809 and $1806 \mathrm{~m}$ a.s.l. for Mt. Cervialto and Terminio massifs, respectively. Locally a series of limestone and limestone-dolomite (Late Triassic-Miocene) outcrops, characterized by a thickness ranging between 2500 and $3000 \mathrm{~m}$, generally extremely faulted and crushed. Along the northern and eastern sectors, these massifs are tectonically overlapped on the terrigenous and impermeable deposits (Fig. 2), constituting argillaceous complexes (Paleocene) and flysch sequences (Miocene). More specific geological insight of the outcropping areas can be found in Parotto and Praturlon (2004) and related literature, and in Geological Map of Italy, 1:50,000 scale (ISPRA 2009).

Pyroclastic deposits of Somma-Vesuvius activity cover the Picentini Mountains, with thickness up to several meters along gentle slopes and only few decimetres along steep slopes. The pyroclastic cover is generally composed of several irregular, ashy pumiceous layers, intercalated with weathered ash deposits; while the pumice layers are composed of coarse material (sand and gravel), the interlayered remoulded and weathered ash deposits are finer materials (sand and silt, with low clay fraction). All these deposits have high water retention values and play an important role in the infiltration of water into the karst substratum.

These massifs are characterized by wide endorheic areas (Fig. 2), which have an important role in the recharge processes. The origin of these endorheic zones is connected to tectonic activity during upper PliocenePleistocene, which has caused a general uplift by direct faults, and formation of graben zones. During the following continental environment (Pleistocene-Holocene), karst processes have transformed these zones in endorheic ones, allowing the complete absorption of runoff, and the formation of seasonal lakes. In particular, the Cervialto Massif is characterised by the several endorheic areas (Fig. 2) where the largest is the Piano Laceno $\left(20.5 \mathrm{~km}^{2}\right)$. Here a small sinking lake exists, which increases during the winter-spring period. As the Caposele Spring can be considered the only spring draining the Cervialto Massif 
(other springs has a considerable lower discharge), this endorheic area constitutes entirely part of the recharge area of this spring. Due to a local cave system, Caliendo Cave, in the West side of the Piano Laceno, only a limited water escape exist from this endorheic area and it is drained in the Calore Valley.

The Caposele Spring (417 $\mathrm{m}$ a.s.l.) is located inside the village of Caposele, at the head of the Sele River (Fig.
2). This spring, locally known also with name of Sanità Spring, is primarily fed by the Cervialto Mountain (Celico \& Civita 1976), and has a mean annual discharge of $3.96 \mathrm{~m}^{3} / \mathrm{s}$. The spring was tapped during the beginning of ninetieths by the Pugliese Aqueduct, which passes through the Sele-Ofanto watershed via a tunnel and supplies the Puglia Region with water as described in the Introduction. The aqueduct constitutes a main grav-

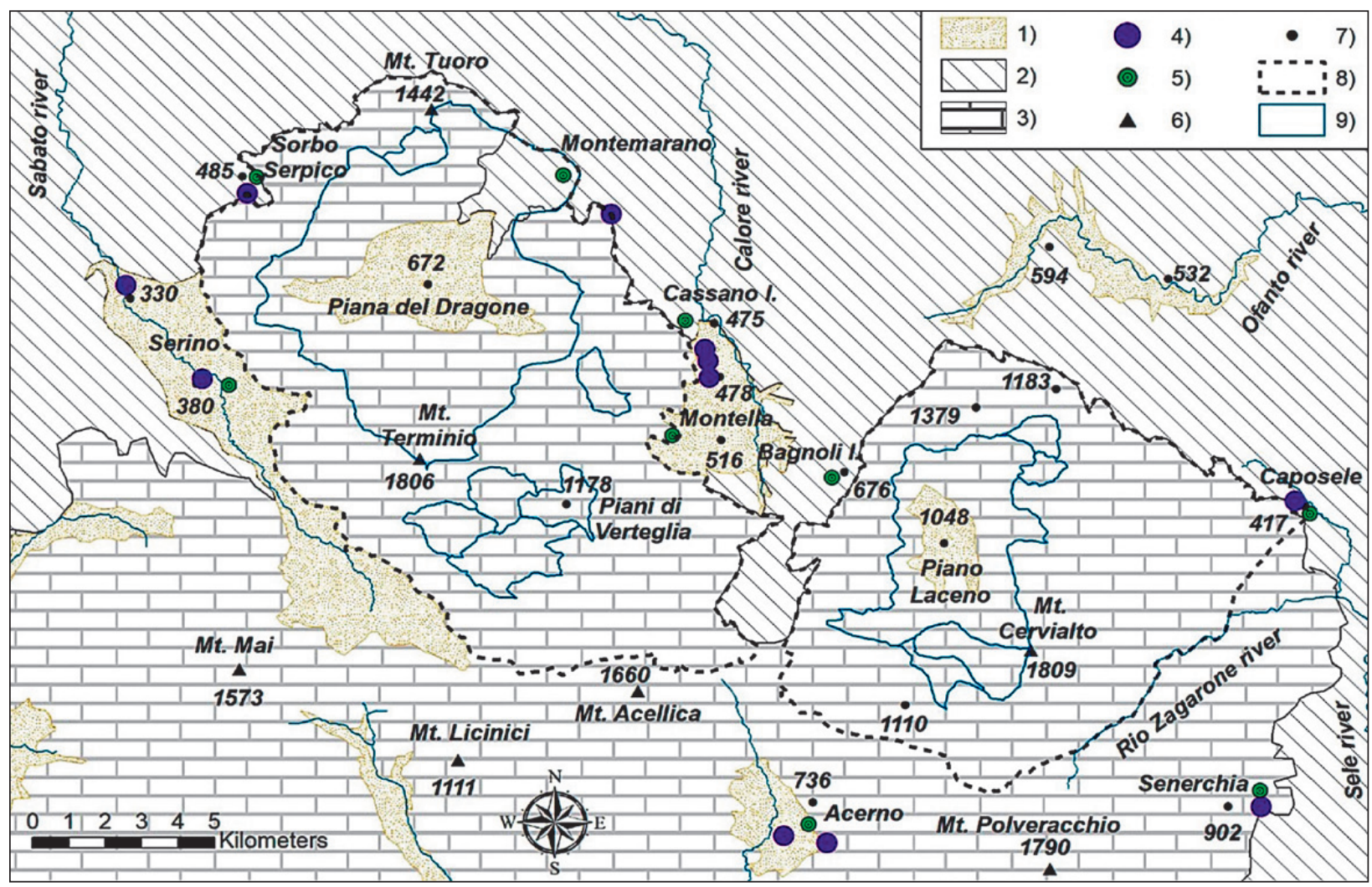

Fig. 2: Hydrogeological sketch of north sector of Picentini Mountains (modified from Fiorillo et al. 2015). 1) Slope breccias and debris, pyroclastic, alluvial and lacustrine deposits (Quaternary); 2) argillaceous complex and flysch sequences (Paleogene-Miocene); 3) calcareousdolomite series (Jurassic-Miocene); 4) main karst spring; 5) village; 6) mountain peak; 7) elevation ( $m$ a.s.l.); 8) Cervialto and Terminio groundwater catchment; 9) endorheic area.

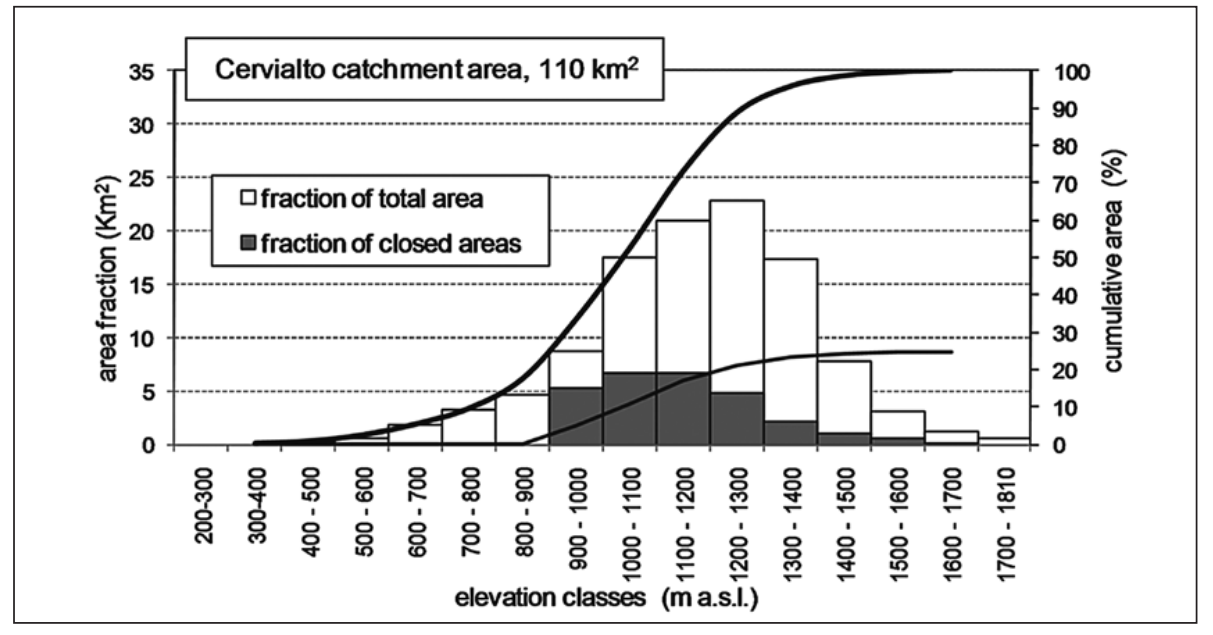

Fig. 3: Elevation classes distribution of Cervialto catchment (modified from Fiorillo et al. 2015). The closed areas (endorheic areas) occupy a quarter of the total catchment. 
ity-channel (244 km long) between Caposele and Villa Castelli (near Brindisi), where 93 bridges and 105 tunnels guaranty a constant slope (between $0.25-0.5 \%$ ); the main tunnel crosses Sele-Ofanto watershed by $15.3 \mathrm{~km}$ long tunnel (Pavoncelli Tunnel), and another long tunnel (about $16 \mathrm{~km}$ ) crosses the Murge reliefs. From the main channel, several branches supply different areas (Foggia, Bari, Brindisi, Matera, etc.), and a wide siphon reaches the Salento area from Villa Castelli.

Other powerful springs are fed by the Terminio Massif and are located in the valley of the Sabato River (Fig. 2), along the north-western boundary of the Picentini Massif (Serino Springs), and in the Calore River basin along the northern boundary of the Picentini Mountains (Cassano Springs). These springs are characterized by upwelling flow (Fiorillo et al. 2018).

The long-term spring discharge measurements and the relation to climate variable have been analysed by Fiorillo and Guadagno (2012), and the hydraulic aquifer behaviour during droughts has been described by Fiorillo (2009) and Fiorillo et al. (2012).

The delimitation of the catchment of Caposele Spring can be approximately carried out looking at the karstified limestone outcrops and at the morphological features of the calcareous area with an elevation higher than spring's; the estimated recharge area is $110 \mathrm{~km}^{2}$, which practically feed only Sanità Spring. The groundwater is drained by a single spring outlet, and it is bounded by impervious terrains; along the southern part, the spring catchment cannot be accurately defined.

The elevation classes distribution of the Cervialto catchment is shown in Fig. 3, where more than $65 \%$ of the catchment lies above $1000 \mathrm{~m}$ a.s.l, with a general mean of $1172 \mathrm{~m}$ a.s.l. The endorheic areas occupy $25 \%$ of the Cervialto Spring catchment and are distributed in the high-elevated zones.

\section{CLIMATE AND HYDROLOGICAL FEATURES}

As the entire Italian peninsula, a typical Mediterranean climate locally exists. It is characterized by dry and warm summers, and wet periods occurring during the fall, winter and spring. Monthly rainfall reaches its highest annual peak during November-December, while the minimum occurs during July-August. In the highly-elevated zones (above $1000 \mathrm{~m}$ a.s.l.) snow can cumulate for several weeks/months during winter, providing a time-shift of infiltration processes.

Fig. 4 shows the distribution of the monthly effective rainfall (difference between monthly rainfall and monthly potential evapotranspiration) for a station at high elevation (Mt. Vergine) located in a nearby karst massif (Mt. Partenio) (Fig. 1). The effective rainfall expresses the amount of rainfall which is free to charge the soil moisture, to percolate and charge the groundwater, or runs off. As can be seen, recharge processes begin generally in October, as the earlier rainfall of August, September and part of October is completely absorbed by the evapotranspiration processes or retained as soil moisture. Runoff can occur after the middle October, and ends after May.

The regime of Caposele Spring appears almost opposite respect to rainfall distribution, as the minimum occurs in November-December and the maximum June. Cassano and Serino spring hydrographs also have floods several months after monthly rainfall peak.

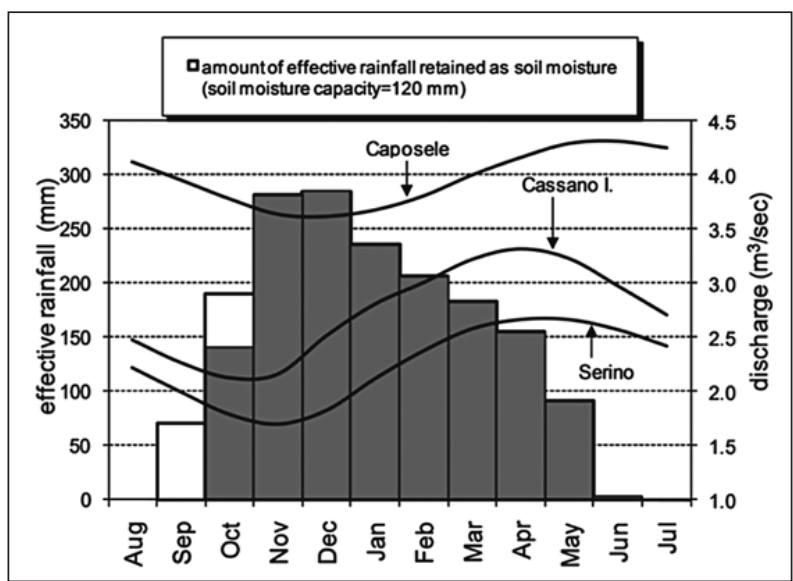

Fig. 4: Mean monthly effective rainfall (Mt. Vergine stations, 1270 $m$ a.s.l.), and mean monthly spring discharges of Caposele, Cassano and Serino Springs. The effective rainfall has been computed as the difference between monthly mean rainfall and the potential evapotranspiration computed by the method of Thornthwaite and Mather (1957).

Historical time series of Caposele, Cassano and Serino Spring discharge are shown in Fig. 5, together with rainfall recorded at Serino rain gauge expressed as annual effective rainfall. Spring discharges show a very similar trend, with drier and wetter years being well correlated between each series. All measured discharges after 1987 show a decrease up to 1993. During this period, many water resource management problems occurred in Southern Italy due to the reduced water supply. The two droughts reflected by the spring discharge series appear to be explained well by the two lowest historical values of annual rainfall, which were recorded during 1949 and 2002 (Fig. 5).

The minimum discharge of Caposele Spring is reached in autumn, and generally is above the threshold of $3 \mathrm{~m}^{3} / \mathrm{s}$, which is reached only under extreme droughts.

As can be seen in Fig. 5, the maximum annual mean discharge of Caposele Spring was reached in 1981. This values was strongly influenced by the earthquake occurred on 23 November 1980, with the epicentre zone 


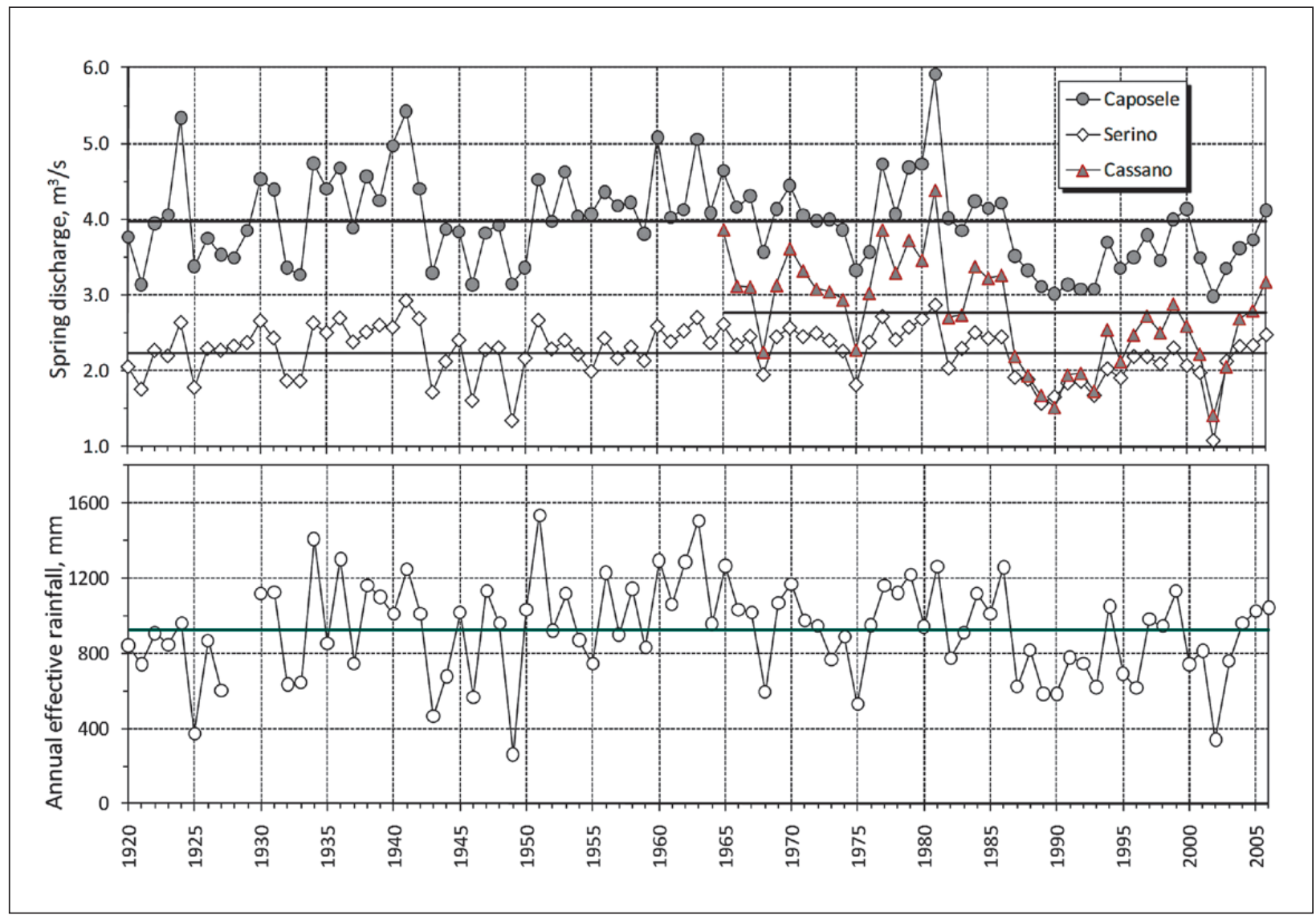

Fig. 5: Annual mean of spring discharge series (Caposele, Cassano and Serino), and annual effective rainfall (Serino rain gauge); thick lines are the mean of series (Caposele Spring, $3.97 \mathrm{~m}^{3} / \mathrm{s}$; Cassano Springs, $2.76 \mathrm{~m}^{3} / \mathrm{s}$; Serino Springs, $2.25 \mathrm{~m}^{3} / \mathrm{s}$; Serino rainfall, $928 \mathrm{~mm}$ ). The annual effective rainfall has been computed as the sum of monthly effective rainfall between September and August for each hydrological year.

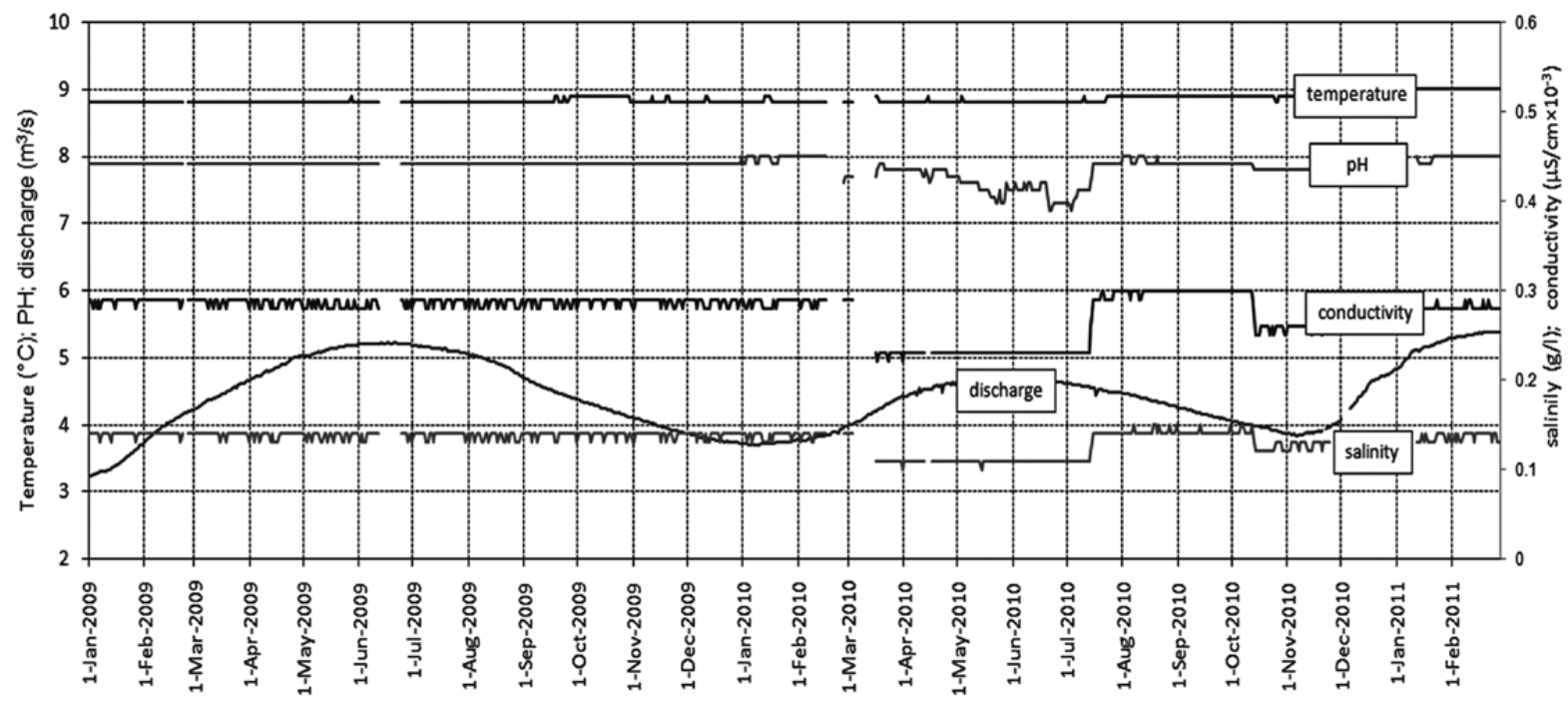

Fig. 6: Daily values of discharge, temperature, pH, salinity, and conductivity of Caposele Spring from 1 January 2009 to 27 February 2011. 
close to Caposele Spring and seismic magnitude Ms=6.9. During this earthquake several springs showed anomalous behaviour (included Serino and Cassano springs), characterised by a rapidly increase of discharge (Celico 1981; Cotecchia \& Salvemini, 1981); some aspects of this anomalous behaviour have been further discussed in Fiorillo (2015).

The discharge of Caposele Spring is not influenced by single rain event (daily rainfall), and the hydrographs have a smooth shape characterized by the absence or a very low component of quick flow. Daily discharge and some physical and chemical characteristics are shown in Fig. 6; temperature is almost constant, around $8.8-9.0^{\circ} \mathrm{C}$; $\mathrm{pH}$ seems decrease from 7.9 up to 7.3 during the high flow period, conductivity (from 300 up to $230 \mu \mathrm{S} / \mathrm{cm}$ ) and salinity (from 0.14 to $0.11 \mathrm{~g} / \mathrm{l}$ ) as well.

In general, all these characteristics indicates that the karst conduits are not well developed or connected (Fiorillo 2009), especially for Caposele Spring. Karst caves are present in many places in the Picentini Mountains, and their presence indicates that dissolution processes have penetrated deeply into the rock mass, thereby forming large karst conduits. The presence of karst caves and wide closed depressions should induce rapid movement of the water from the surface to the springs, which would result in a quick flow component in the spring hydrograph. However, recent tectonic activity may have resulted in the development of faults and fractures that have obstructed the karst conduits and transformed limestone rocks into breccias. As know, karst conduits easily develop into poor fractured calcareous rocks, where bedding and isolated spaced fractures are able to concentrate the percolation water. Locally some faults were reactivated during the 1980 Irpinia earthquake, leaving clear traces of superficial faulting (Papanikolaou \& Roberts 2007). Therefore, the local rock mass conditions (heavily fractured and crushed) and the active tectonic may provide an explanation for the absence of a quick flow component from analysed hydrographs. Also the thick unsaturated zone, between Caposele Spring (417 $\mathrm{m}$ a.s.l.) and the ground surface (elevation mean $1179 \mathrm{~m}$ ) favours long period of percolation.

In addition, the pyroclastic mantle reduces rapid infiltration into the karst system, which may also contribute to the smoothed shape of the spring hydrographs, especially when it has deficit in soil moisture. Fiorillo and Wilson (2004) described the role that rainfall plays in recharging surface and deep aquifer systems covered by pyroclastic deposits in the Campania Region investigating the variation in wetness on the pyroclastic mantle. During the dry season (summer), the water content of the pyroclastic cover reaches a minimum, whereas the water content increases to field capacity during autumn; subsequent storms cause water to percolate into deep layers and recharge the groundwater aquifer. The amount of rainfall required to increase the minimum water content to field capacity has been estimated in $120 \mathrm{~mm}$ (Fiorillo et al. 2015).

Above $1000 \mathrm{~m}$ a.s.l., precipitation often occurs as snow during winter, which can also induce a delay in the infiltration processes.

\section{HYDRAULIC BEHAVIOUR DURING DROUGHTS}

The lack of precipitation over a large area and for extensive periods of time is known as meteorological drought. This water deficit propagates through the hydrological cycle and gives rise to different types of droughts. If groundwater recharge and stream flow will be reduced a hydrological drought may develop, and it is temporally shifted with respect to meteorological droughts (Tallaksen \& Van Lanen 2004). A long meteorological drought can induce the lowering of piezometric levels and spring discharges, causing a groundwater drought, which is a specific aspect of the hydrological drought.

During a dry hydrological year as consequence of a limited recharge processes, spring discharges have values lower than the mean; practically, the water volume provided by recharge processes is almost always smaller than that discharged at spring. In particular, during a groundwater drought the spring discharge falls to minimum values and highlights the behaviour of the spring under such extreme hydrological condition. Under extreme conditions, the spring hydrograph shows a continuous decrease trend for the entire hydrological year (Fiorillo 2009), and the hydraulic behaviour under dry periods and droughts can be analysed (Fiorillo 2011, 2014).

Fig. 7 shows the groundwater drought of 1949 induced by the poor annual rainfall of 1948-49. The annual rainfall is shown in Fig. $7 \mathrm{~b}$, where the values are standardized (mean $=0$; standard deviation $=1$ ) from long time series, by the following equations:

$Q_{s}=\frac{Q_{i}-\mu}{\sigma} ; \quad P_{S}=\frac{P_{i}-\mu}{\sigma}$

where $Q_{s}$ and $P_{s}$ are the standardized values of the annual mean discharge, $Q_{i}$, and annual rainfall, $P_{i}$, respectively; $m$ and $s$ are the mean and standard deviation of the respective time series.

The annual rainfall of 1948-49 was 2.65 standard deviations below the mean, and presents an extreme meteorological drought in southern Italy (Fiorillo \& Guadagno 2010, 2012). During the following year 1949-50, the annual rainfall was almost as the mean value, but Caposele Spring still had a discharge one standard deviation below the mean, indicating that it maintains the memory effect 
of the antecedent drought year. During the 1949-50, the Serino Springs had discharge value near the mean and didn't show a memory effect of the antecedent drought. This different hydraulic behaviour highlights the influence of hydrological conditions of the antecedent year on large springs, as Caposele, responding to long accumulation of rainfall. Observing Figure 5, it can be seen clearly that this phenomenon occurred also after the extreme drought of 2002, and it will be considered later in evaluating the recharge processes.

\section{RECHARGE ESTIMATION}

Recharge can be defined as the downward flow of water reaching the water table (de Vries \& Simmers 2002). Precipitation that is not lost by evapotranspiration and runoff, included that accumulates into soil without percolating downward, constitutes the recharge here. Even if karst rocks allow high rate of infiltration, runoff occurs especially along steep slopes and for high rainfall intensity. In the endorheic areas the runoff is completely adsorbed (internal runoff; White 2002). This occurs in the endorheic areas of Cervialto Massif, which constitute important recharge for the Caposele Spring. Outside endorheic areas, the runoff can escape from the spring catchment, especially during intense storms. These areas are namely 'open areas' (Fiorillo et al. 2015) and constitute the difference area between the spring catchment area and the endorheic areas.

Fiorillo et al. (2015) estimated the amount recharge on karst massifs, based on daily scale model, calibrated on a long-term annual scale. The amount of evapotranspiration, recharge, and runoff was estimated for the Terminio and Cervialto massifs, and a similar approach was also used for the Matese Massif (Fiorillo \& Pagnozzi 2015).

In this study the recharge model of Fiorillo et al. (2015) has been applied for several recent hydrological years, and the behaviour of Caposele aquifer after dry and wet years has been investigated.

The equations described in Fiorillo et al. (2015) are below briefly described.

The annual model is based on GIS analyses, where the afflux, evapotranspiration and effective rainfall on the catchment are estimated. The spatial distribution of the rainfall allows estimation of the total amount of the afflux, $F$, in a specific area, $A$, by:

$(F)_{A}=\frac{\sum_{1}^{n} P}{n} \times A$

where $n$ is the number of cells in the area $A$, and $P$ is the annual mean rainfall assigned to each cell in function of its ground-elevation, and deducted from the regression of available rain gauges, located at different ground-elevation.

If the effective rainfall, $P_{e f p}$ is defined by subtracting the actual ev apotranspiration, AET, from the rainfall, the effective afflux, $F_{e f p}$ in a specific area, $A$, is:

$\left(F_{e f f}\right)_{A}=\frac{\sum_{1}^{n} P_{e f f}}{n} \times A$

In endorheic areas, $A_{E}$, as the runoff cannot escape, the
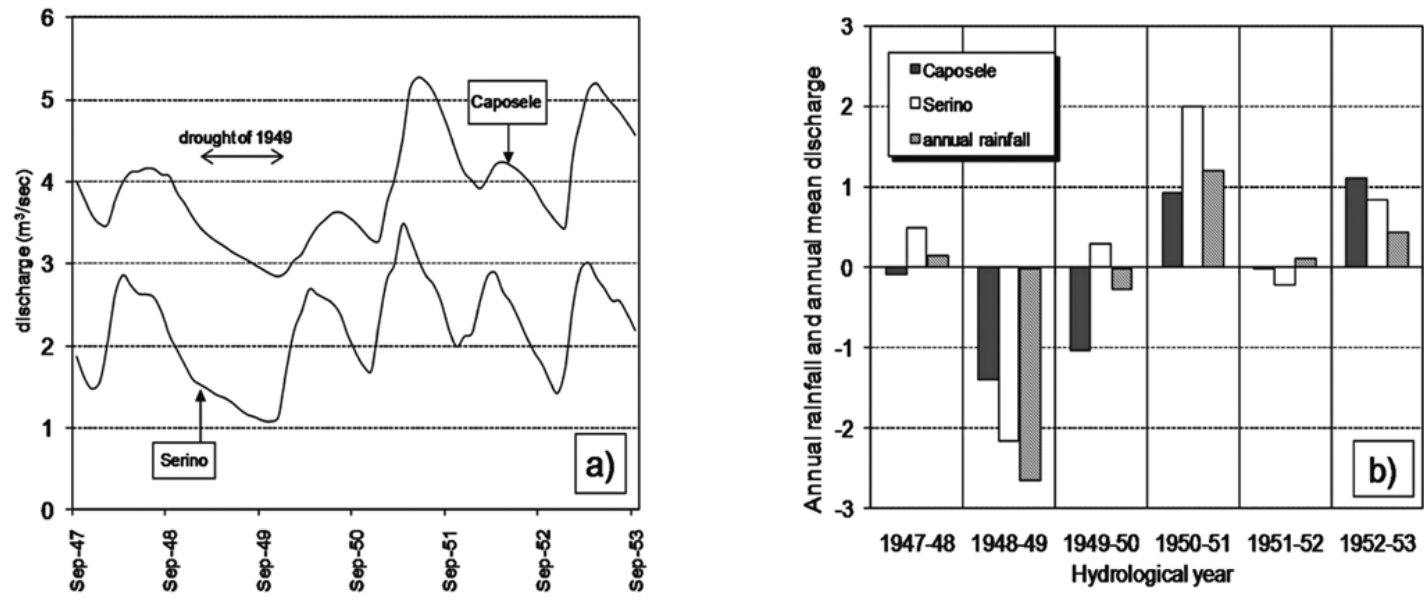

Fig. 7: a) Caposele and Serino spring discharge during the period September 1947-September 1953; the groundwater drought of 1949 is marked by the continuous decreasing discharge. b) standardised annual rainfall and annual mean discharge (period 1920-2009); the groundwater drought of 1949 was induced by the meteorological drought of 1948-49, and continued during 1949-50 in Caposele Spring (modified from Fiorillo 2015). 
recharge amount, $R$, can be considered equal to effective afflux, $F_{\text {eff: }}$

$(R)_{A_{E}}=\left(F_{e f f}\right)_{A_{E}}$

In the open areas, $A_{o}$, the recharge amount, $(R)_{A o}$, can be estimated assuming that all the groundwater flow feeds the spring discharges, $Q_{s}$, and no-flow boundaries occurs towards argillaceous, terrigenous and flysch sequences (impervious terrains). Following this assumption, the total discharge, $Q_{s}$, from springs is:

$Q_{s}=(R)_{A_{E}}+(R)_{A o}$

which allows to obtain the recharge in the open areas:

$(R)_{A o}=Q_{s}-\left(F_{\text {eff }}-Q_{P}\right)_{A_{E}}$

where $Q_{p}$ is the total amount of water abstracted by pumping. The total recharge on the catchment area, $A_{C}$, is:

$(R)_{A c}=(R)_{A o}+(R)_{A_{E}}=Q_{S}-Q_{P}$

Recharge can be expressed in term of fraction of the effective afflux, providing the effective recharge coefficient, $C_{R}$. If water pumping does not occur, $Q_{P}=0$, the following equations can be deducted:

$\left(C_{R}\right)_{A_{E}}=1 ;\left(C_{R}\right)_{A_{O}}=\frac{(R)_{A_{o}}}{\left(F_{\text {eff }}\right)_{A_{O}}} ;\left(C_{R}\right)_{A c}=\frac{(R)_{A c}}{\left(F_{\text {eff }}\right)_{A c}}$

In general, these coefficients express the infiltration capacity of karst slopes and depend on the slope angle distribution, vegetation, soil type, and on the degree of karstification.

The daily model is based on the balance of water content of the soil mantle provided by (Fiorillo $\&$ Wilson 2004), transforming the daily rainfall in water content, up to field capacity, and then to recharge and runoff.

In particular, the daily rainfall, $P_{i}$, is divided into several parts:

$P_{i}=A E T+\Delta \Theta+R+R O$

where $A E T$ is the actual evapotranspiration, $\Delta \Theta$ constitutes the increase of water content of the soil, $R$ is the recharge, and $R O$ is the runoff.

During no-rainfall periods $\left(P_{i}=0\right)$, both $R$ and $R O$ are nil and the equation 9 reduces to: $-\triangle \Theta=A E T$

describing the soil moisture decrease as consequence of evapotranspiration processes at daily scale up to a minimum value of the soil moisture, $\Theta_{\min }$. The AET depends on the soil moisture, $Q$ :

$A E T=P E T$ for $\Theta>\Theta_{\text {min }} ; A E T=0$ for $\Theta=\Theta_{\text {min }}$

where PET, the potential evapotranspiration, is computed adapting the Thornthwaite model (Thornthwaite \& Mather 1957) at daily scale (Fiorillo \& Wilson 2004).

During wet periods, the soil moisture can increase up to a maximum value, $\Theta_{\max }$, above which the water cannot be retained as retention water and has to percolate throughout the soils or runoff. The value $\Theta_{\max }$ can be approximated to field capacity of the soil. Thus, when field capacity has been reached, recharge, $R$, and runoff, $R O$, can occur. This amount of rainfall, the excess rainfall, $P_{\text {exc }}$ :

$P_{e x c}=R+R O$

is the rainfall that can either recharge the aquifer, $R$, and the runoff, $R O$. In this model the amount $\Delta \theta+R$ constitutes the infiltration.

In the endorheic areas, $A_{E}$, as the runoff, $R O$, cannot escape from the catchment. There all the excess rainfall, $P_{e x c}$ is recharge:

$\left(P_{\text {exc }}\right)_{A_{E}}=(R)_{A_{E}}$

In the open areas, $A o$, the model assumes that runoff occurs if rainfall excess, $P_{\text {exc }}$, exceeds a specific threshold value, $T_{r}$, at daily scale:

for $P_{e x c} \leq T_{r}, \quad\left(P_{e x c}\right)_{A_{O}}=(R)_{A_{O}}$

for $P_{\text {exc }}>T_{r},\left(P_{\text {exc }}\right)_{A_{o}}=(R)_{A_{O}}+(R O)_{A_{o}}$, and $(R)_{A_{o}}=T_{r}$

The threshold value, $T_{r}$, corresponds to the infiltration capacity at daily scale when soil reached field capacity. $T_{r}$ is deducted imposing in the simulation, for a specific hydrological year, the ratio between the annual recharge amount in open areas, $\Sigma(R)_{A 0^{\circ}}$, and annual excess rainfall, $\Sigma P_{\text {exc }}$ (both computed summing daily values), equal to $\left(C_{R}\right)_{A o}^{\text {exc }}$ computed at long-term annual scale (equation 8). In particular, the threshold can be estimated considering several hydrological years characterized by annual rainfall near the mean.

Some variables need to be fixed on the basis of in situ and laboratory tests, and allow to carry out a simulation of the evapotranspiration and recharge processes 
on daily scale. In particular, the soil moisture capacity is needed, which depends on the thickness of the soil involved in the evapotranspiration processes and on the range of the soil moisture during the hydrological year $\left(\Theta_{\max }-\Theta_{\min }\right)$.

Fiorillo and Wilson (2004) estimated for the pyroclastic mantle of Campania slopes the following characteristics:

- the (volumetric) water content at field capacity, $\Theta_{\max }=51 \%$;

- the minimum water content reached at the end of dry season (summer), $\Theta_{\min }=27 \%$;
- the total porosity, $n=0.56$, and the effective porosity, $n_{\text {eff }}=0.06$.

For a soil thickness undergoing evapotranspiration processes can be assumed a mean value of $H=50 \mathrm{~cm}$; all these soil characteristics provide a soil storage capacity, $m=120$ $\mathrm{mm}$. However, because the soil mantle thickness cannot be considered constant, the above values has to be consider only as useful approximation to evaluate the mean characteristics of these soil mantle.

Solid precipitations (snow) are not considered in the model, and this can cause the overestimation of the runoff in the open areas, as snowmelt favourites recharge processes.

\section{RESULTS AND DISCUSSION}

Table 1 shows the main morphological and hydrological characteristics of the Cervialto Massif, evaluated by GIS tools.

Following the long term annual scale recharge model, the afflux, runoff, recharge amount, and recharge coefficients have been estimated. Table 2 shows the result obtained, where values of each endorheic area are also reported.

The transformation of daily rainfall in daily recharge has been carried out by equation 9, using the Laceno rain gauge which is characterized by annual mean rainfall similar that the entire karst massif. This rain gauge appears usefully located, as the annual mean rainfall (2014 $\mathrm{mm}$ ) reflects the annual mean afflux of Cervialto Massif $(2109 \mathrm{~mm})$ (Tab. 1). However, it worked discontinuity in the past; since 2007 a new rain gauge station is working and seems to measure more accurately the precipitation (liquid and solid).The recharge of the recent six hydro-

Tab. 1: Results of main hydrological parameters of Cervialto catchment by GIS tools.

\begin{tabular}{|l|c|c|c|}
\hline Parameter & Mean & Max & Min \\
\hline Elevation (m a.s.l.) & 1179 & 1809 & 417 \\
\hline Afflux (mm/year) & 2109 & 2621 & 1529 \\
\hline Temperature $\left({ }^{\circ} \mathrm{C}\right)$ & 8.5 & 13.5 & 4.4 \\
\hline Actual evapotranspiration $(\mathrm{mm})$ & 529 & 688 & 410 \\
\hline
\end{tabular}

Tab. 2: Main hydrological parameters of endorheic (closed) areas, open areas, and entire spring catchment of Caposele Spring (Cervialto Massif), after the long scale recharge model. $F$, afflux; $F_{\text {eff }}$ effective afflux; $R O$, runoff; $R$, recharge; $C_{R}$, effective recharge coefficient (simplified from Fiorillo et al. 2015).

\begin{tabular}{|c|c|c|c|c|c|c|c|c|c|}
\hline \multicolumn{2}{|c|}{ Springs } & \multirow{2}{*}{ Area } & \multirow{2}{*}{ Item } & \multirow{2}{*}{$\mathbf{k m}^{2}$} & \multirow{2}{*}{$\underset{\mathrm{m}^{3} \times 10^{6}}{F}$} & \multirow{2}{*}{$\underset{\mathrm{m}^{3} \times 10^{6}}{\boldsymbol{F}_{\text {eff }}}$} & \multirow{2}{*}{$\begin{array}{c}R O \\
\mathrm{~m}^{3} \times 10^{6}\end{array}$} & \multirow{2}{*}{$\begin{array}{c}R \\
\mathrm{~m}^{3} \times 10^{6}\end{array}$} & \multirow{2}{*}{$C_{R}$} \\
\hline Group & $\mathrm{m}^{3} / \mathrm{s}$ & & & & & & & & \\
\hline \multirow{3}{*}{ Caposele } & \multirow{3}{*}{3,96} & Piano Laceno & 1 & 20.5 & 43.8 & 32.9 & 0.0 & 32.9 & 1 \\
\hline & & Piano Acernese & 2 & 3.3 & 7.4 & 5.8 & 0.0 & 5.8 & 1 \\
\hline & & Piano dei Vaccari & 3 & 1.4 & 3.0 & 2.3 & 0.0 & 2.3 & 1 \\
\hline \multirow{3}{*}{$\begin{array}{l}\text { Bagnoli } \\
\text { Irpino }\end{array}$} & \multirow{3}{*}{0,07} & Valle Rotonda & 4 & 1.1 & 2.3 & 1.8 & 0.0 & 1.8 & 1 \\
\hline & & Raia dell'Acera & 5 & 0.7 & 1.5 & 1.2 & 0.0 & 1.2 & 1 \\
\hline & & Closed areas, $A_{E}$ & - & 27.0 & 58.0 & 44 & 0.0 & 44.0 & 1 \\
\hline \multirow{2}{*}{ Others } & \multirow{2}{*}{0,10} & Open areas, $A_{0}$ & - & 83 & 172.4 & 128.3 & 43.8 & 84.5 & 0.66 \\
\hline & & Springs catchment, $A_{c}$ & - & 110 & 230.4 & 172.3 & 43.8 & 128.5 & 0.75 \\
\hline
\end{tabular}


Tab. 3: Cumulative recharge for each year of Fig. 8, compared with cumulative discharge observed at Caposele Spring; the difference, $\delta$, expresses the surplus (positive) or the deficit (negative) water volume into the aquifer.

\begin{tabular}{|c|c|c|c|}
\hline Hydrological year & $\begin{array}{c}\text { Cumulative recharge } \\
\left(\mathbf{m}^{3} \times \mathbf{1 0}^{6}\right)\end{array}$ & $\begin{array}{c}\text { Cumulative discharge } \\
\left(\mathbf{m}^{3} \times 10^{6}\right)\end{array}$ & $\begin{array}{c}\text { Difference, } \delta \\
\left(\mathbf{m}^{3} \times 10^{6}\right)\end{array}$ \\
\hline $2010-11$ & 156.77 & 152.17 & 4.60 \\
\hline $2011-12$ & 91.30 & 114.61 & -23.31 \\
\hline $2012-13$ & 159.57 & 125.53 & 34.04 \\
\hline $2013-14$ & 139.48 & 132.69 & 6.80 \\
\hline $2014-15$ & 102.43 & 121.65 & -19.22 \\
\hline $2015-16$ & 109.22 & 112.21 & -2.98 \\
\hline
\end{tabular}

logical years, from 2010-11 to 2015-2016 (Fig. 8a) has been simulated; some years were wet as the 2010-11, 2012-13 and 2013-14 (annual rainfall above the mean); the 2011-12 was dry (annual rainfall below the mean). In the daily scale simulation (Fig. 8b), following the equation 9, during the initial period (September-October) the daily rainfall is transformed in soil moisture increase, net of evapotranspiration. When field capacity has been reached, corresponding to a soil cover retained value of $120 \mathrm{~mm}$, daily rainfall is able to provide the daily rainfall excess amount, $\mathrm{P}_{\text {exc }}$; the amount of recharge and runoff are estimated by equations 13,14 and 15 . The threshold value $T_{r}=22.3$ was fixed on the basis of the simulation of hydrological year 1973-74, characterized by annual rainfall near the mean (Fiorillo et al. 2015). In this way, rainfall excess that exceeds $22.3 \mathrm{~mm}$ is transformed in runoff in open areas.

Fiorillo et al. (2015) also discussed the variation of the effective recharge coefficient, $\left(C_{R}\right)_{A o}$, during wet and dry years.

The cumulative recharge for each year is shown in Table 3, and it has been compared with the cumulative

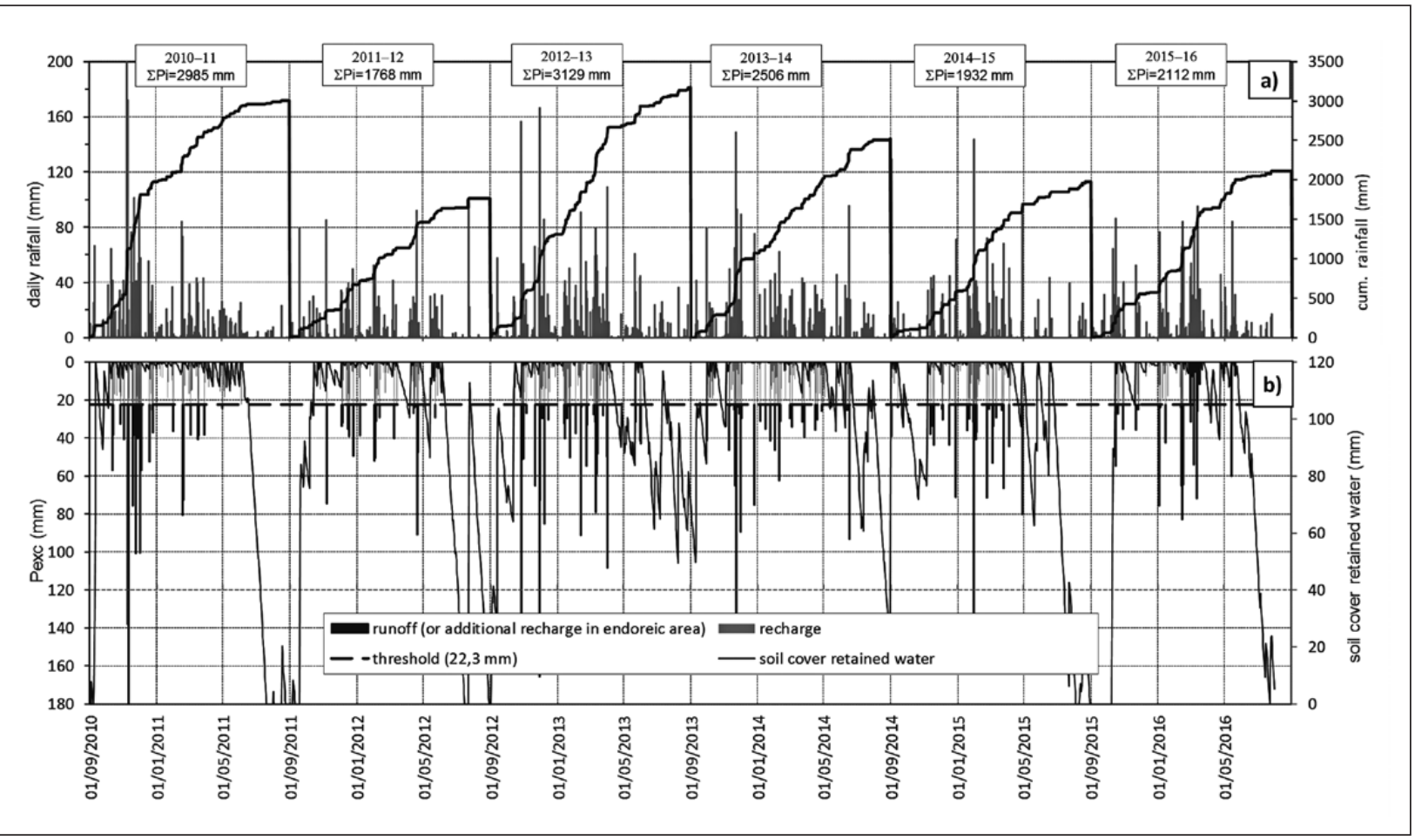

Fig. 8: a) Daily and cumulative rainfall from 2010-11 to 2015-16 hydrological years, Laceno rain gauge (1170 $m$ a.s.l.). b) daily scale recharge model, showing the simulation of the volumetric water content (soil cover retained water), recharge and runoff; the threshold of 22.3 $m m$ splits the excess daily rainfall, $P_{\text {exc }}$, in daily recharge and daily runoff. 
discharge observed at Caposele Spring. As can be seen, the difference, $\delta$, between this two values in the same years is not null, and highlights the inertial behaviour of the aquifer. In particular, after a dry year (as the 2011-12), the observed volume discharged at the spring is higher than the estimated recharge volume. After wet years, the recharge volume tends to be higher than the discharged volume, especially if wet years occur after dry years. This behaviour was also investigated analysing the statistical distribution of the annual mean values following the wetter and drier years of the historical distribution (Fiorillo 2009), but here has been analytically estimated.

The results indicate that during dry years a deep aquifer emptying occurs, which causes a deficit of storage in the aquifer and reduces discharge during the following year. During wet years, the water spring discharged volume tends to be lower than recharged volume. In general, this aquifer behaviour indicates the presence of a mem-
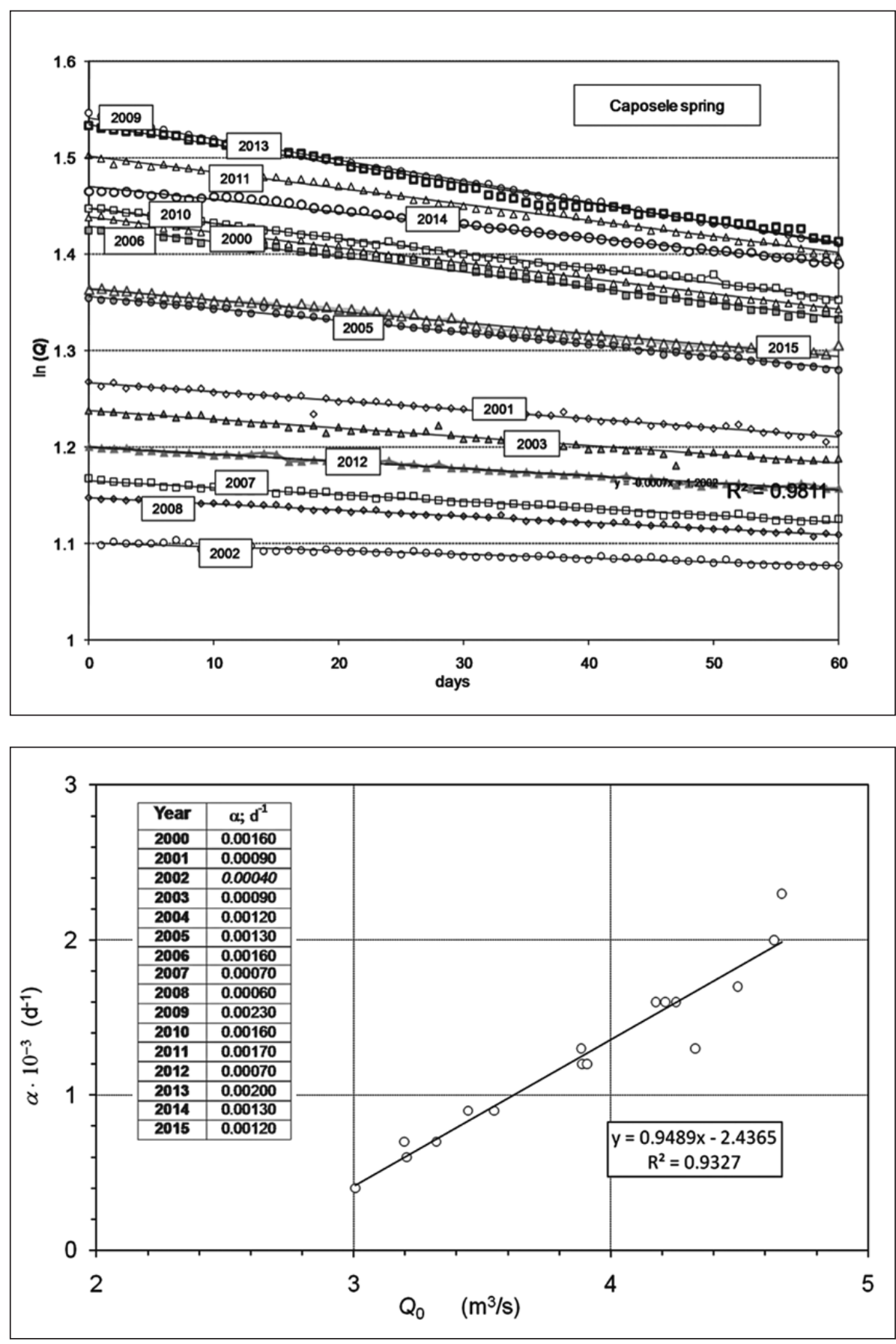

Fig. 9: Natural logarithms of the Caposele daily discharges during the recession period. Day 0 is $1^{\text {th }}$ September for 2000-2015 and $6^{\text {th }}$ April for 2002; no data are shown for 2004.
Fig. 10: Relation between the recession coefficient, $\alpha$, and spring discharge at the beginning of the draining, $Q_{0}$ for the years 2000 2015. 
ory effect of antecedent years, and favor a useful natural regulation of aquifer for management purposes.

After the anomalous discharge induced by the 1980 earthquake, the following years were characterized by values below the mean during the following two years (1982 and 1983). Also in this case, the aquifer system has compensated the exceptional water volume discharged after the 1980 earthquake, reducing the discharge during the following years.

The inertial behaviour of the aquifer has to connect to its slow response to recharge input, due to the extension of catchment, the thickness of the vadose zone and the karst conditions of the rock mass.

Under the long dry Mediterranean season, the Caposele Spring is characterized by a slow and continuous decrease of the discharge; the characteristics of the hydrographs under such conditions are shown in Fig. 9, where recession segments of the Caposele Spring hydrographs have been plotted in semilogarithmic plot. A straight line fits the recorded data, and the recession coefficient (the slope of the line generated from the equation) was calculated for each year considered and showed in Fig. 10. The strong dependence of the recession coefficient on the discharge at beginning of the recession period, $Q_{0}$, has been discussed by Fiorillo (2014): as the recession coefficient, $\alpha$, decreases under drought conditions, the Caposele Spring guarantees water during the long dry Mediterranean period and can be considered drought-resistant.

This type of hydraulic behaviour has been connected to the increase of the effective porosity in depth, inside the epiphreatic zone (Fiorillo 2011, 2014), and could have role in the inertial behaviour of the aquifer.

\section{CONCLUSIONS}

The recharge processes have been investigated for the Caposele Spring catchment, which is characterised by wide endorheic areas in a typical karst mountain area of the Apennine.

Due to Mediterranean climate and hydrogeological characteristic of aquifer, recharge generally begins during middle-late autumn and ends in middle spring, and it is characterized only by autogenic recharge.

The aquifer has large area, and has an extraordinary capacity to regulate the annual climate fluctuations. After wet years, an amount of water volume is retained into the aquifer and constitutes the surplus of volume stored, whereas, after dry years, the aquifer discharges a water volume higher than the recharged volume, and accumu- lates a deficit in storage. These characteristics have been estimated for six hydrological years by a specific recharge model, and the developed model allows improving the water management of the Caposele Spring.

The results found are calibrated on the basis of recent detailed hydrologic survey in the spring catchment area, as the accurate precipitation records in middle ground elevated zone of aquifer by rain gauge and snow gage, runoff measurement in several gullies of the massifs. Two different systems for water content measurement of the soil cover have been placed in the Piano Laceno and Piana del Dragone areas, which could improve the simulation at daily scale of the recharge model.

\section{REFERENCES}

Celico, P., 1981: Relazioni tra l'idrodinamica sotterranea e terremoti in Irpinia (Campania) (Hydrodynamical underground relationship in Irpinia (Campania).- Rendiconti della Società Geologica Italiana, 4, 103-108.

Celico, P. \& M. Civita, 1976: Sulla tettonica del massiccio del Cervialto (Campania) e le implicazioni idrogeologiche ad essa connesse.- Bollettino della Società Naturalisti, Naples, 85, 555-580.
Cotecchia, V. \& A. Salvemini, 1981: Correlazione tra eventi sismici e variazioni di portate alle sorgenti di Caposele e Cassano Irpino, con particolare riferimento al sisma del 23 novembre 1980.- Geologia Applicata e Idrogeologia, 16, 167-192.

De Vries, J.J. \& I. Simmers, 2002: Groundwater recharge: an overview of processes and challenges.- Hydrogeology Journal, 10, 5-17. DOI: 10.1007/s10040-0010171-7 
Fiorillo, F., 2009: Spring hydrographs as indicators of droughts in a karst environment.- Journal of Hydrology, 373, 3-4, 290-301. DOI: 10.1016/j.jhydrol.2009.04.034

Fiorillo, F., 2011: Tank-reservoir emptying as a simulation of recession limb of karst spring hydrographs.- Hydrogeology Journal, 19, 1009-1019. DOI: 10.1007/ s10040-011-0737-y

Fiorillo, F., 2014: The recession of spring hydrographs focused on karst aquifers.- Water Resources Management, 28, 1781-1805. DOI: 10.1007/s11269-0140597-Z

Fiorillo, F., 2015: Hydraulic behaviour of karst aquifer.In: Z. Stevanović (ed.) Karst Aquifers, Characterization and Engineering.- Springer, Switzerland, pp. 421-434.

Fiorillo, F. \& A. Doglioni, 2010: The relation between karst spring discharge and rainfall by the cross-correlation analysis.- Hydrogeology Journal, 18, 18811895. DOI: $10.1007 / \mathrm{s} 10040-010-0666-1$

Fiorillo, F. \& F.M. Guadagno, 2010: Karst spring discharges analysis in relation to drought periods, using the SPI.- Water Resources Management, 24, 1867-1884. DOI: $10.1007 / \mathrm{s} 11269-009-9528-9$

Fiorillo, F. \& F.M. Guadagno. 2012: Long karst spring discharge time series and droughts occurrence in Southern Italy.- Environmental Earth Sciences, 65, 8, 2273-2283. DOI: 10.1007/s12665-011-1495-9

Fiorillo, F. \& M. Pagnozzi, 2015: Recharge processes of Matese karst massif (southern Italy).- Environmental Earth Sciences, 74, 7557-7570. DOI: 10.1007/ s12665-015-4678-y

Fiorillo, F. \& R.C. Wilson, 2004: Rainfall induced debris flows in pyroclastic deposits, Campania (southern Italy).- Engineering Geology, 75, 3, 263-289. DOI: 10.1016/j.enggeo.2004.06.014

Fiorillo, F., Esposito, L., Testa, G., Ciarcia, S. \& M. Pagnozzi, 2018: The upwelling water flux feeding springs: hydrogeological and hydraulic features.Water (MDPI), 10, 4, 501. DOI: 10.3390/w10040501
Fiorillo, F., Pagnozzi M. \& G. Ventafridda, 2015: A model to simulate recharge processes of karst massifs.Hydrological Processes, 29, 10, 2301-2314. DOI: 10.1002/hyp.10353

Fiorillo F., Revellino P. \& G. Ventafridda, 2012: Karst aquifer draining during dry periods.- Journal of Cave and Karst Studies, 74, 2, 148-156. DOI: 10.4311/2011JCKS0207

ISPRA, 2009: Geological map of Italy, 1:50.000 scale. [Online] Available from: http://www.isprambiente. gov.it/en/publications/reports/geological-map-ofitaly-in-scale-1-50-000-carg [Accessed February $\left.18^{\text {th }}, 2019\right]$.

Papanikolaou, I.D. \& G.P. Roberts, 2007: Geometry, kinematics and deformation rates along the active normal fault system in the southern Apennines: implications for fault growth.- Journal of Structural Geology, 29, 166-188. DOI: 10.1016/j.jsg.2006.07.009

Parotto, M. \& A. Praturlon, 2004: The Southern Apennine Arc.- In: Crescenti, U., D’Offizi, S., Merlino, S. $\&$ L. Sacchi (eds.) Special volume of the Italian Geological Society. 32 ${ }^{\text {nd }}$ International Geological Conference, 34-58. Florence.

Tallaksen, L.M. \& H.L.J. Van Lanen, 2004: Hydrological Drought: Processes and Estimation Methods for Stream Flow and Groundwater, Elsevier, pp. 579, Amsterdam.

Thornthwaite, C.W. \& J.R. Mather, 1957: Instructions and tables for computing potential evapotranspiration and the water balance.- Publication in climatology, vol. 10. Drexel Institute of Technology, Centerton, New Jersey, pp. 132.

White, W.B., 2002: Karst hydrology: recent developments and open questions.- Engineering Geology, 65, 85105. DOI: $10.1016 /$ S0013-7952(01)00116-8 